\title{
MENJINAKKAN BARAT DENGAN OKSIDENTALISME: GAGASAN KIRI ISLAM HASSAN $\underline{\text { HANAFî }}$
}

\author{
Suharti
}

\section{Abstract}

In the scholarly thoughts, some recognized Muslim scholars are among them: Nashr Hamîd Abûu Zayd, Zia Ghokap, Mubammad Syahrûr, Amina Wadûd, and $\underline{\text { Hassan }}$ $\underline{H}$ anafi. They were known for their brilliant ideas and theories in perceiving problems and finding ways out of the problems related either to Islamic affairs and the Muslims or even for the welfare of the whole bumankind. The ideas that they offered through writings become inspirations and triggers to Islamic development to compete with the West.

It is relative to consider one's idea as extraordinary or ordinary. In this case, Hassan Hanafi, as one of Muslim scholars, tried to offer an idea popularly known as "al-Yasâr al-Islâmî" or "Islamic Left". The idea proposed in the "Islamic Left" is an effort to bring back Islam and the Muslims to the previous golden era by eliminating every threat to Islam. This revolution is based on three main considerations: revitalization of classical literature, reality of Islamic world and the needs to fight against western civilization.

This article is intended to trace the path of the existence of "Islamic Left" developed by $\underline{H}$ assan $\underline{H}$ anafí from historical background, terminology, school of thoughts, and $\underline{H}$ assan Hanafî's way of thinking.

Keywords: Kiri Islam, Revitalisasi, Khazanah Klasik, Dunia Islam, Barat, Orientalisme, Oksidentalisme.

HASSAN Hanafî bukanlah nama yang asing, terutama bagi kalangan intelektual muslim Indonesia yang "gemar" dengan tema-tema sekitar kebangkitan Islam. ${ }^{1}$ Bagi Hanafî, kebangkitan Islam adalah kebangkitan rasionalisme untuk menghidupkan kembali (revitalisasi) khazanah Islam klasik, di samping melakukan perlawanan wacana terhadap dominasi kebudayaan Barat dan menganalisis kembali realitas dunia Islam. Hanafî

${ }^{1}$ Hassan Hanafi, Oksidentalisme: Sikap Kita terhadap Tradisi Barat, ter. M. Najib Buchari (Jakarta: Paramadina, 2000), xi. 
adalah pemikir muslim radikal dan kritis, baik terhadap gerakan Islam maupun gerakan Barat yang mencoba mendominasi Islam.

Hanafî memperoleh pendidikan tingginya; magister dan doktor di Universitas Sorbonne, Prancis. Di samping tradisi pemikiran Islam, tradisi pemikiran Barat juga dikuasainya dengan baik. Melalui kapabilitas dan

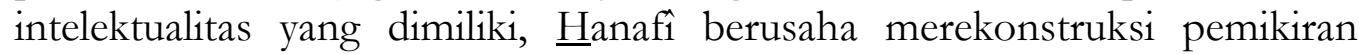
Islam ke arah yang dapat membebaskan pemikiran umat Islam dari segala bentuk penindasan.

Dari sekian banyak tulisan atau karyanya, "al-Yasâr al-Islâmı̂" (Kiri Islam) merupakan salah satu puncak sublimasi pemikirannya setelah revolusi Islam di Iran meletus pada tahun 1979. Melalui Kiri Islam, walaupun baru memuat tema-tema pokok dari proyek besar revolusionernya, Hanafî telah memformulasikan satu kecenderungan pemikiran yang ideal tentang bagaimana seharusnya sumbangan agama bagi kesejahteraan umat manusia.

Dalam tulisan ini, penulis akan membahas gagasan $\underline{H}$ assan $\underline{H}$ anafî tentang konsep Kiri Islam, yang mencakup latar belakang kemunculannya, metodologi pemikirannya, maupun ide-ide yang terdapat dalam gagasan Kiri Islam tersebut. Selanjutnya akan dicobaketengahkan bagaimana Hassan Hanafî dalam berkarya dan mengembangkan kualitas intelektualnya.

\section{Biografi Intelektual}

Hassan Hanafî adalah seorang reformis dan pemikir Islam (filosuf). Terlahir di Kairo Mesir pada tanggal 13 Pebruari 1935.² Pendidikannya diawali dari pendidikan dasar dan tamat pada tahun 1948, kemudian melanjutkan studinya di Madrasah Tsanawiyah "Khalil Agha" Kairo, selesai tahun 1952. Selama belajar di tingkat Tsanawiyah, ia aktif mengikuti diskusidiskusi kelompok Ikhwân al-Muslimîn. Karena itu, sejak kecil ia telah mengetahui pikiran-pikiran yang dikembangkan Ikhwân al-Muslimîn dan para aktivis sosialnya. Di samping itu, Hanafî tertarik juga mempelajari pemikiran-pemikiran Sayyid Quthb, terutama prinsip-prinsip keadilan sosial dalam Islam. ${ }^{3}$

Pada tahun 1952, ㅂanafî melanjutkan studinya ke Departemen Filsafat Universitas Kairo, dan selesai pada tahun 1956 dengan menyandang gelar

John L Esposito, The Oxford Encyclopedia of the Modern Islamic World (New York: Oxford University Press, 1995), 98.

${ }^{3}$ E. Kusnadiningrat, Teologi dan Pembebasan: Gagasan Islam Kiri Hassan Hanafi (Jakarta: Logos, 1999), 49. 
Sarjana Muda. Dalam periode ini, Hanafî merasakan situasi yang paling buruk di Mesir. Pada tahun 1954, terjadi pertentangan keras antara Ikhwân al-Muslimîn dan gerakan Revolusi. Dalam arus pertentangan itu, Hanafí berada pada pihak Muhammad Najîb yang berhadapan dengan gerakan Nasser, karena baginya Najîb memiliki komitmen dan visi keislaman yang jelas.

Kejadian-kejadian yang ia alami pada masa itu membuatnya bangkit menjadi seorang pemikir, pembaru, dan reformis. ${ }^{4}$ Keprihatinan yang muncul dan selalu bergolak dalam batinnya saat itu adalah mengapa umat Islam selalu dapat dikalahkan dan mengapa konflik internal harus dan terus terjadi?

Selanjutnya, pada tahun yang sama, Hanafî memperoleh kesempatan untuk belajar di Universitas Sorbonne Prancis. Di sini ia memperoleh lingkungan yang kondusif untuk mencari jawaban atas persoalan-persoalan mendasar yang sedang dihadapi oleh negerinya dan sekaligus merumuskan jawaban-jawabannya. Di Prancis inilah ia dilatih untuk berpikir secara metodologis melalui kuliah-kuliah maupun bacaan-bacaan atau karya-karya sejumlah orientalis. Ia juga sempat belajar pada seorang reformis Katolik, Jean Gitton tentang metodologi berpikir, pembaruan, dan sejarah filsafat. Ia sempat juga belajar tentang fenomenologi dari Paul Ricour, analisis kesadaran dari Edmund Husserl, dan bimbingan penulisan tentang pembaruan ushûl al-fiqh di bawah supervisi Professor Massignon. ${ }^{5}$

Akhirnya, pada tahun 1966, $\underline{\text { Hanafi }}$ berhasil menyelesaikan jenjang pendidikan S2 dan S3-nya. Dalam perjalanan karir akademiknya, mulai sejak tahun 1967, ia (dapat) diangkat menjadi "Lektor", kemudian menjadi “Lektor Kepala" tahun 1973. Puncaknya pada tahun 1980, ㅍanafî diangkat sebagai "Professor" (guru besar) filsafat pada Jurusan Filsafat di Universitas Kairo. Selanjutnya, pada tahun 1988, ia menjabat sebagai ketua jurusan pada universitas yang sama. ${ }^{6}$ Di samping itu, Hanafî memberi kuliah di berbagai tempat; di antaranya di Perancis (1969), Belgia (1970), Temple University Philadelpia Amerika (1971-1975), dan Universitas Fez, Maroko (1982-1984). Selanjutnya, ia diangkat sebagai guru besar tamu pada Universitas Tokyo

${ }^{4}$ Ibid.

${ }^{5}$ Ibid., 50.

"Thaha Mahasin, "Manusia dan Perubahan Sejarah Berteologi Bersama Hassan Hanafi,” BANGKIT, No. 8, III (1994), 23. 
(1984-1985), sampai dia menjadi penasehat program pada Universitas PBB di Tokyo Jepang tahun 1985-1987.

Selama kunjungan ke beberapa negara tersebut ia gunakan untuk mempelajari berbagai tradisi dan budaya setempat, mencermati situasi-situasi sosial, politik, dan ekonomi. Sehingga, ia dapat menambah wawasan untuk semakin mempertajam pemikirannya dalam memahami persoalan dalam dunia Islam. Di samping kegiatan di atas, ia juga menyempatkan diri untuk berkecimpung dalam organisasai kemasyarakatan, khususnya yang berkaitan dengan dunia filsafat, seperti keaktifannya sebagai sekretaris umum pada ogranisasi "Persatuan Masyarakat Filsafat Mesir". Ia juga aktif menjadi anggota dalam "Ikatan Penulis Asia-Afrika". Selain itu, ia menjadi anggota solidaritas Asia-Afrika dan juga menjadi "Wakil Presiden Masyarakat Filsafat Arab". 7

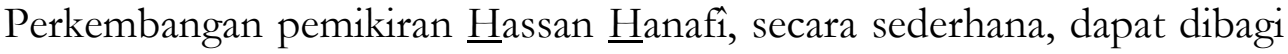
menjadi tiga periode. Pertama, periode tahun 1960-an. Pada tahun-tahun ini, pemikirannya banyak dipengaruhi oleh paham yang berkembang di Mesir, yaitu sekitar sosialistik, nasionalistik, dan populistik yang dirumuskan dalam ideologi Pan-Arabik. ${ }^{8}$ Pada rentang masa ini ia banyak merekonstruksi pemikiran Islam yang menurutnya sedang mengalami krisis. Dalam rangka itu ia banyak melakukan penelitian, terutama dalam metode interpretasi sebagai upaya pembaruan ushûl fiqh dan fenomenologi sebagai metode untuk memahami agama dalam konteks realitas kontemporer. Berbagai penelitan yang ia lakukan, pada gilirannya, mengantarnya mendapat gelar doktor.

Kedua, fase tahun 1970-an. Pada fase ini ia banyak berbicara tentang problema kontemporer sebagai upaya untuk mencari jawaban atas kekalahan Islam ketika perang melawan Israel tahun 1967. Dalam hal ini ia mencoba menggabungkan antara semangat keilmuan dan kerakyatan; ia menyadari bahwa seorang ilmuwan tidak hanya duduk berpikir, tapi juga harus memberikan jalan keluar ketika masyarakat luas mengalami kesulitan. ${ }^{9}$ Dalam kerangka ini, ia banyak menulis, seperti tulisannya yang berjudul "Qadlâyâ Mu’âshirah fî Fikrinâ al-Mu'âtsir I” pada tahun 1976. Selanjutnya, pada

${ }^{7}$ Ibid., 23-4.

'Abdurrahman Wahid, "Hassan Hanafi dan Eksperimentasinya," Pengantar dalam Kazuo Shimogaki, Kiri Islam Antara Modernisme dan Posmodernisme: Telaah atas Pemikiran Hassan Hanafi, ter. M. Imam Aziz dan M. Jadul Maula (Yogyakarta: LKiS, 1994), xii.

'Yudian, "Gerakan Pemikiran Kiri Islam: Studi atas Pemikiran Hassan Hanafi", Jurnal Hukum Islam al-Mawrid, edisi VII (1999), 82. 
tahun 1977, ia menulis kembali dengan judul “Qadlâyâ Mu'âshirah fî Fikri alGharbî II". Ketegangan yang terjadi di Mesir antara pemerintah dan kelompok Islam radikal yang kemudian memicu terbunuhnya presiden Mesir Anwar Sadat yang memberikan kelonggaran kepada Israel pada tahun 1981 mengilhami Hanafî menyusun tulisan yang berupa himpunan artikelnya, menjadi 8 jilid buku dengan judul "al-Dîn wa al-Tsawrah fî Mishr 19521981”, yang dihimpun sejak tahun 1976-1981 yang selanjutnya diterbitkan pada tahun 1987. Sementara karya lainnya adalah "Religious Dialogue and Revolution (1972-1976)" yang diterbitkan pada tahun 1977. Karya lainnya adalah "Dirâsah Islâmiyyah" yang ditulisnya sejak tahun 1978, kemudian diterbitkan pada tahun 1981.10

Ketiga, fase tahun 1980-an dan awal 1990-an. Dilatarbelakangi oleh situasi pemerintah yang stabil dibanding tahun-tahun sebelumnya, ia menulis kembali beberapa tulisan seperti tulisan yang berjudul "al-Turâst wa alTajdîd" yang terbit pertama kali pada tahun 1980. Buku ini memuat dasardasar ide pembaruan dan langkah-langkahnya. Tulisan lainnya juga muncul, yaitu “al-Yasâr al-Islâmî” yang berbau ideologi. Pada tahun 1988, Hanafî menulis pula 5 jilid buku yang berjudul "al-'Aqîdah ilâ al-Tsawrah" yang ditulisnya selama 10 tahun. Pada tahun 1985-1987, ia sempat menulis buku yang berjudul "Religion, Ideology, and Development" yang merupakan kumpulan artikel.

Dari sekian pengalaman yang diperoleh, dapat ditegaskan bahwa $\underline{H}$ assan Hanafî adalah seorang ilmuwan yang aktif, gigih, dan memiliki perhatian besar bagi kehidupan beragama (Islam) dan bangsa. Perhatiannya itu ia tuangkan dalam gagasan "Kiri Islam". Oleh karena itu, kiranya dipandang perlu mengetahui tentang bagaimana kemunculan "Kiri Islam" dalam tradisi pemikiran intelektual muslim.

\section{Latar Ide}

Istilah "Kiri Islam" telah dikenal sejak kemunculan Jurnal "al-Yasâr alIslâmî" yang diterbitkan pada tahun 1981. Istilah ini sebenarnya bukanlah

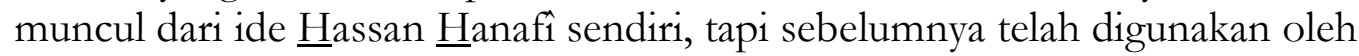
Ahmad Ghabbas Shâlih dalam tulisannya, "al-Yamîn wa al-Yasâr fî al-Islâm" (1972). Dalam buku ini, istilah tersebut diartikan dengan pengertian

${ }^{10}$ Kusnadiningrat, Teologi..., 58. 
"Sosialistik dalam Islam". ${ }^{11}$ Selanjutnya, oleh Hanafí dipandang baik untuk dikembangkan dengan pengertian "mengangkat posisi kaum yang dikuasai, kaum tertindas, kaum miskin, dan menderita", atau dengan kata lain, "perlawanan dan kritisisme". 12

Kemunculan Kiri Islam sangat dipengaruhi oleh semangat revolusi Iran yang meletus tahun 1979. Selain itu juga, ia dipengaruhi oleh gerakan lainya di dunia Islam Arab, berupa: pertama, adanya kecenderungan keislaman yang terkait dengan kekuasaan dan berubahnya praktik keislaman yang hanya menjadi ritus. Kecenderungan semacam itu dilihat oleh $\underline{\text { Hanafî dapat }}$ mengarah kepada sikap feodalisme dan kapitalisme kesukuan. Kedua, adanya kecenderungan liberal yang dominan sebelum terjadi revolusi Arab yang secara kultur berasal dari Barat, walaupun mereka menganggap imperialisme sebagai musuh. Ketiga, adanya kecenderungan-kecederungan Marxis-Barat yang ingin membangun suatu kemampuan yang menentang imperialisme, sementara kaum muslimin tidak bisa mengembangkan khazanahnya sendiri. Dan keempat, ada gejala-gejala revolusi nasional yang menimbulkan perubahan mendasar dalam struktur sosial-budaya, tetapi tidak melibatkan kesadaran kaum muslimin. ${ }^{13}$

Walaupun Jurnal "al-Yasâr al-Islâmî" hanya sekali terbit, ia merupakan teks penting untuk ditelaah. Penting, dikarenakan beberapa hal. Pertama, tercapainya revolusi Islam di Iran memberikan pengaruh besar, khususnya terhadap dunia Arab. Jurnal tersebut adalah salah satu teks terbaik yang dapat digunakan untuk menelaah pengaruh revolusi ini terhadap intelektual muslim-Arab. Kedua, "al-Yasâr al-Islâmî" bukan semata-mata sebuah respons Hanafi terhadap revolusi Islam Iran. Ide-ide senafasnya yang lain dalam "Revolusi di Dunia Ketiga" dan "Agama dan Revolusi” patut pula dikaji. Dua karya ini mengungkap respons intelektual Hanafî dalam konteks sosial politik modern.

Selanjutnya, ketiga, "al-Yasâr al-Islâmî” merupakan teks yang penting bagi studi mengenai perkembangan gerakan Islam modern, terutama kalau dipandang gerakan-gerakan baru ini sebagai bagian dari proses yang dimulai

${ }^{11}$ Kazuo Shimogaki, Kiri Islam Antara Modern dan Posmodernisme: Telaab atas Pemikiran Hassan Hanafi, ter. M. Imam Aziz dan M. Jadul Maula (Yogkarta: LKiS , 1994), 6.

${ }^{12}$ Hassan Hanafi, Al-Yasar al-Islami: Paradigma Islam Transformasi, ter. Saiful Muzani dari appendiks monografi Kazuo Shimogaki, Between Modernity and Post-Modernity: the Islamic Lefi and Dr. Hassan Hanafi's Thought, A Critical Reading (Tokyo: IMES-IUJ Working Paper Series, No. 14, September 1988), 4.

13Ibid., 4-5. 
dari Jamâl al-Dîn al-Afghânî. Memang jurnalnya disebut sebagai penerus Jurnal "Urwah al-Wutsqâ" yang diterbitkan oleh al-Afghânî dan Muhammad "Abduh. Keempat, "al-Yasâr al-Islâmî" merupakan teks pemikiran Islam. Dalam hal ini dapat diselidiki hubungan antara kekuatan politik, kesejahteraan kaum muslim, dan (bahkan) rasionalisme.

Kemudian, kelima, dalam "al-Yasâr al-Islâmı̂”, Barat selalu dibutuhkan untuk didudukkan sebagai ancaman terhadap Islam dan untuk itu diposisikan sebagai objek telaah. Dalam hal ini, Hanafî mencoba mengembangkan suatu ilmu sosial baru, yaitu "oksidentalisme" yang ia pertentangkan dengan "orientalisme". Dan terakhir, keenam, "al-Yasâr alIslâmî" merupakan refleksi atas kebingungan di lingkungan sosial-politik dunia Arab dan intelektual Arab, terutama kaum intelektual yang mengalami penindasan; dan ketujuh, beberapa persoalan pokok yang menjadi kepedulian "al-Yasâr al-Islâmî" adalah kolonialisme, kapitalisme, zionisme, dan dukungan atas dunia Islam yang datang dari luar. Di samping itu, juga masalah kemiskinan, penindasan, dan keterbelakangan yang datang dari dunia Islam sendiri. ${ }^{14}$

Jadi, kemunculan "al-Yasâr al-Islâmî" atau "Kiri Islam” bukanlah dengan sendirinya, tapi dilingkupi oleh suasana pemerintahan, tradisi pemikiran, pengaruh luar, dan sejumlah faktor lain. Yang demikian itu lahir sebagai hal yang alami, karena memang manusia hidup akan selalu dikitari problem, dan akan muncul pula rivalnya sebagai penentang problem itu. Demikian pula yang dialami Hanafî dengan munculnya "Kiri Islam" sebagai counter solution atas problem kekinian umat Islam.

\section{Epistemologi Kiri Islam}

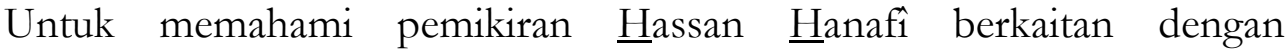
munculnya gagsan Kiri Islam, maka ada beberapa hal penting untuk diketahui. Pertama, perannya sebagai pemikir revolusioner. Dalam konteks ini, ia terdorong untuk memunculkan gagasan Kiri Islam bersamaan dengan meletusnya revolusi Islam di Iran. Maka, salah satu tugas Kiri Islam adalah mencapai "revolusi tawhî̀ d", sebagai suatu konsep inti dalam pandangan dunia Islam. Atas dasar itu, maka ia dikategorikan sebagai pemikir revolusioner semisal 'Alî Syarî'atî, di mana pemikirannya merupakan tulang

${ }^{14}$ Shimogaki, Kiri Islam..., 10-4. 
punggung revolusi Iran, dan Ayatullâh Khomeini yang memimpin revolusi Iran dengan sukses.

Kemudian, kedua, $\underline{\text { Hassan }} \underline{\mathrm{H}}$ anafî adalah seorang reformis dalam tradisi Islam klasik. Di sini ia berada pada posisi yang dekat dengan 'Abduh, seorang ulama Mesir terkemuka (1849-1905). Dalam hal ini, ia sangat mengagumi 'Abduh. Dan, ketiga, ia juga berposisi sebagai penerus gerakan Al- Afghânî (1838-1896) yang menyerukan persatuan umat Islam, di samping juga menyerukan persatuan dunia Islam, dan perjuangan melawan imperialisme budaya Barat. ${ }^{15}$

Secara garis besar, "Kiri Islam" bertopang pada tiga pilar utama untuk mewujudkan kebangkitan Islam, revolusi Islam, dan kesatuan umat (Islam). Pertama, revitalisasi khazanah Islam klasik. Dalam hal ini, Hanafî dengan tegas menekankan perlunya rasionalisme. Rasionalisme itu merupakan keniscayaan bagi kemajuan dan kesejahteraan untuk memecahkan situasi kekinian dalam dunia Islam. Kedua, perlunya menentang peradaban Barat.

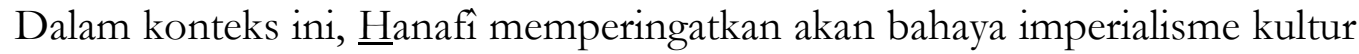
Barat yang cenderung membasmi kebudayaan bangsa-bangsa yang kaya secara historis.

Selanjutnya, pilar ketiga, analisis atas realitas dunia Islam. Hanafî mengkritik metode penafsiran tradisional yang bertumpu pada teks (nash). Karena itu, ia mengusulkan suatu metode tertentu agar realitas dunia Islam dapat berbicara bagi dirinya sendiri. ${ }^{16}$ Analisis terhadap realitas dunia Islam ini merupakan bagian dari metode yang dibangun Hanafî dalam mewujudkan cita-cita Kiri Islam. Pergerakan dan peradaban yang dibangunnya itu disebabkan oleh ketajaman analisis Hanafî dalam melihat realitas dunia Islam. Baginya, makna realitas adalah sebangun dan searti dengan realitas masyarakat, realitas politik dan ekonomi, realitas khazanah Islam, dan (realitas) tantangan Barat. Keberhasilan mencapai cita-cita revolusi Islam tergantung pada kecermatan menganalisis realitas-realitas itu. Untuk menganalisis realitas itu, Hanafî menggunakan metode fenomenologi dengan harapan dunia Islam dapat berbicara bagi dirinya sendiri. ${ }^{17}$

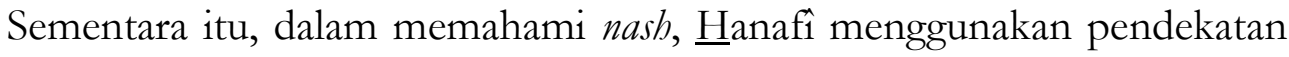
hermeneutika yang telah menjadi bagian dari tema penting dalam pemikirannya, bahkan ia menjadi bagian integral dari wacana pemikirannya

15Ibid., 4.

16Ibid., 5.

${ }^{17}$ Ibid. 
dalam filsafat atau teologi dalam rangka memahami nash tadi. Baginya, hermeneutika bukan sekedar "ilmu interpretasi" terhadap al-Qur'an semata, tapi juga ilmu yang menjelaskan wahyu sejak diturunkannya, mulai dari tingkat perkataan sampai ke tingkat dunia, ilmu tentang proses penerimaan wahyu dari huruf sampai tingkat kenyataan, dari logos sampai praksis, dan juga transformasi wahyu dari pikiran Tuhan ke kehidupan manusia. ${ }^{18}$

Menurut Hanafî, proses pemahaman hanya menduduki tingkat kedua. Sedangkan yang pertama adalah kritik menyangkut kesejarahan, yang menjamin keaslian kitab suci dalam sejarah; dan tidak mungkin akan terjadi pemahaman, bila tidak ada kepastian bahwa apa yang dipahami itu asli secara historis. Di sinilah hermeneutika muncul sebagai ilmu pemahaman dalam arti yang paling tepat, berkenaan terutama dengan bahasa dan keadaan-keadaan kesejahteraan yang melahirkan kitab-kitab suci itu. Setelah diketahui arti yang tepat dari teks tersebut, dapat dimasuki langkah ketiga, yaitu proses menyadari arti yang terpatri dalam konteks kehidupan manusia, yang merupakan tujuan akhir wahyu Allah. ${ }^{19}$

Di samping itu, Hanafî juga melakukan pengkajian keislaman melalui pendekatan eklektik. ${ }^{20}$ Pendekatan ini dipakai oleh $\underline{\text { Hanafî untuk }}$ membangun pemikiran (baca: reaktualisasi), dengan cara memilih pemikiran suatu madzhab seperti kecenderungannya pada teologi $\mathrm{Mu}^{\text {'tazilah, filsafat }}$ Ibn Rusyd, dan fiqh Mâlikî. Pilihan terhadap model-model pemikiran tersebut, sesungguhnya diorientasikan dalam rangka membangun idiologi gerakan transformatif. ${ }^{21}$

Fokus kerangka berpikir Hanafî dalam menegakkan gagasan Kiri Islam-dalam arti membela kelompok tertindas, terpinggir, dan dikuasaiadalah menentang tiga ancaman besar bagi Islam, yaitu imperialisme, zionisme, dan keterbelakangan umat. Imperialisme yang dimaksud di sini adalah (cara) petualangan ekonomi multinasional dan westernisasi kebudayaan. Dalam hal budaya, imperialisme mematikan semangat kreativitas bangsa-bangsa, dan pada saat bersamaan mencabutnya dari akar sejarah mereka. Barat menginginkan agar warisan bangsa-bangsa menjadi entitas historis belaka, kemampuan kreatifnya dibelenggu, juga kebudayaan mereka diubah menjadi budaya museum, yaitu hanya untuk studi an sich.

${ }^{18}$ Hassan Hanafi, Dialog Agama dan Revolusi I (Jakarta: Pustaka Firdaus, 1994), 1.

${ }^{19}$ Ibid.

${ }^{20}$ A.H. Ridwan, Reformasi Intelektual Islam (Yogyakarta: Pustaka Firdaus, 1994), 1.

${ }^{21}$ Hanafi, Dialog...., 6-8. 
Untuk itu, tugas Kiri Islam adalah terus-menerus mengingatkan akan model kolonialisasi baru, adanya rasisme Barat yang tersembunyi, dan perang Salib historis.

Sementara zionisme yang menjadi ancaman kedua memiliki sasaran bukan hanya sekedar tanah, tapi juga menyebarkan pemikirannya ke kalangan intelektual Islam-Arab, seraya mengetahui pemikiran mereka untuk kemudian menghancurkannya. Dan termasuk hal yang bahaya adalah (konsep-konsep) yang datang dari luar, seperti kapitalisme yang dibangun atas dasar perilaku ekonomi bebas, laba, rente, dan riba. Kapitalisme ini di samping dapat mendatangkan dampak penindasan, juga dapat menumbuhkembangkan nilai-nilai destruktif dan hedonisme utilitarian. Hal ini akan berujung pada penciptaan kelas-kelas sosial dan kesenjangan akses, yang pada gilirannya dapat memusatkan otoritas pada tangan pemilik modal, yang mengakibatkan yang miskin semakin miskin dan yang kaya semakin kaya. Padahal, kesemuanya secara tegas ditolak oleh Islam.

Selain itu, menjalarnya kemiskinan, ketertindasan, dan keterbelakangan sebagai ancaman internal. Dalam hal ini, Hanafî berkomentar: "Dalam teks al-Qur'an dijelaskan bahwa kita adalah umat yang satu, tetapi dalam realitasnya terdapat kesenjangan di mana kita terbelah menjadi dua, yaitu umat miskin dan kaya". 22 Selanjutnya, tugas Kiri Islam adalah melakukan redistribusi kekayaan di antara kaum muslimin dengan seadil-adilnya, dengan mengambil hak kaum miskin dari orang kaya, sebagaimana yang diperintahkan al-Qur'an. ${ }^{23}$

Hassan Hanafí juga menegaskan bahwa keterbelakangan merupakan watak murni dunia Islam, yang tidak terjadi dalam pembangunan saja, tetapi (gejala tersebut) menyeluruh, baik menyangkut struktur sosial atau dalam pandangan dunia secara umum. Keterbelakangan yang paling berbahaya menurutnya adalah yang menyangkut kebudayaan dalam kaitannya dengan pandangan dunia, perilaku bangsa, sistem sosial serta ekonomi, dan pemikiran yang merupakan pandangan terhadap dunia yang dualistik, hierarkis-piramidal, dan mistis-mitologis. Dari itu, tugas Kiri Islam adalah menguak misi kesejarahan Islam dan mentrasformasikan mayoritas rakyatnya dari belenggu kuantitas kepada tataran kualitas.

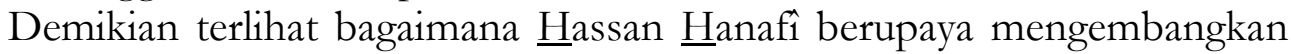
gagasan Kiri Islam dengan metode dan kerangka pemikiran yang dipandang

${ }^{22}$ Ibid.

23Perhatikan al-Qur'an surat al-Ma'ârij (70): 24-5. 
layak, serta dapat mengantarkan umat Islam dalam kerangka menemukan jati diri dan meraih kemenangan dalam segala bidang. Kiranya, bahasan ini tidak sempurna jika hanya diketahui tentang sekelumit motode dan kerangka berpikir Hanafî sebagai seorang pemikir muslim kontemporer, tanpa dikaji lebih lanjut pokok-pokok pemikirannya yang digagas dalam rangka membangun dunia Islam yang "baru" melalui Kiri Islam yang ia kembangkan.

\section{Pikiran Terpokok}

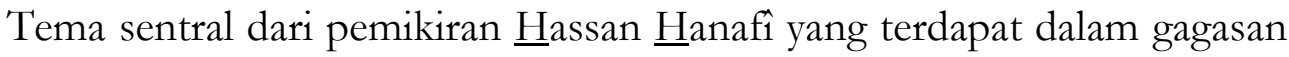
Kiri Islam dapat dikategorikan menjadi agenda besar pembaruannya. Seluruhnya dapat diklasifikasi pada tiga isu besar, yakni (1) revitalisasi khazanah Islam klasik; (2) Urgensi penentangan atas peradaban Barat; dan (3) realitas faktual dunia Islam.

Revitalisasi Khazanah Islam Klasik. Bagi Hassan Hanafî, rekonstruksi, pembangunan, dan pemurnian khazanah (Islam) klasik sangat penting dilakukan. Sebab Kiri Islam sendiri berakar pada dimensi revolusioner dan juga khazanah Islam klasik. Dalam hal ini, $\underline{H}$ anafî membagi khazanah Islam klasik menjadi beberapa ilmu pengetahuan, yaitu, pertama, ilmu-ilmu rasional-tradisional, seperti ilmu ushûl al-dîn, ushôl al-figh, filsafat, dan sufisme. Kedua, ilmu-ilmu rasional, seperti matematika, astronomi, fisika, kedokteran, dan farmasi. Ketiga, ilmu-ilmu tradisional seperti ilmu al-Qur'an, ilmu hadîst, sirah Nabi Muhammad saw, fiqh, dan tafsîr. ${ }^{24}$

Dalam hal itu, yang ia maksudkan dengan "revolusi khazanah Islam klasik" adalah unsur rasionalistik yang dapat mendukung paham kebebasan manusia dan demokrasi. Unsur tersebut itulah yang dimaksudkan dengan ke"kiri"-an yang dalam hal ini, antara lain, menunjuk kelompok Mu'tazilah. Sementara, lawannya adalah Asy'ariyah, sebagai kelompok "kanan". Demikian juga dalam hal fiqh, madzhab Mâlikiyah sebagai "kiri", dan fiqh Hanafiyah sebagai "kanan". Kemudian dalam bidang tafsir, tafsîr bi al-Ra'y sebagai "kiri”" dan tafsîr bi al-Ma'tsur sebagai "kanan". ${ }^{25}$

Kiri Islam, sebagai paradigma yang independen dalam pemikiran,

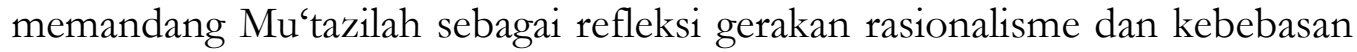

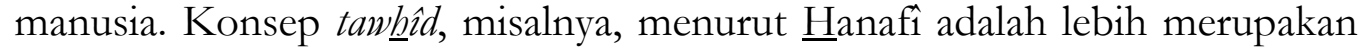
prinsip rasional murni daripada konsep personifikasi, sebagaimana yang

${ }^{24}$ Hanafi, Al-Yasar..., 6.

25Ibid., 6-8. 
menjadi keyakinan Asy'ariyah. Kiri Islam berupaya mengenal dan menghidupkan kembali pemikiran Mu'tazilah untuk membangun rasionalisme dalam paham kebebasan. ${ }^{26}$

Perlunya Menentang Peradaban Barat. Menurut Hanafi, sebagai kelanjutan al-'Ur'wah al-Wutsqâ, Kiri Islam memiliki keterkaitan dengan agenda al-Afghânî, yaitu melawan kolonialisme dan keterbelakangan, yang menyerukan kebebasan dan keadilan sosial, serta (berhasrat) mempersatukan kaum muslim yang telah terpecah-belah dalam banyak blok. Tugas Kiri Islam adalah mengembalikan kebudayaan Barat ke batas alamiah dan mengakhiri mitosnya yang (telah) mendunia. ${ }^{27}$ Dengan kata lain, tugas Kiri Islam adalah mendorong peradaban Barat sebagai tema studi khusus, objek telaah, bagi peradaban non-Barat.

Berkaitan dengan hal itu, Hanafî lalu mengusulkan "oksidentalisme" sebagai (kajian) tandingan bagi "orientalisme" dalam rangka mengakhiri mitos Barat dimaksud. Hal itu dapat dilakukan dengan memperhatikan dua arah; aspek perkembangan dan strukturnya. Sebab, biasanya suatu perkembangan melahirkan struktur, tapi peradaban Barat berkembang sebelum adanya struktur, sehingga struktur dilahirkan oleh perkembangannya. Peradaban itu sendiri dapat dikelompokkan menjadi dua, yaitu (1) sentripetal di mana ilmu berkeliling di seputar satu pusat, dan (2) sentrifugal di mana ilmu itu keluar dari pusat. Dalam konteks ini, tandas Hanafî, peradaban Islam bersifat sentripetal dan peradaban Barat bersifat sentrifugal. ${ }^{28}$

Realitas Dunia Islam. Gagasan Kiri Islam sesungguhnya memberikan gambaran riil situasi dunia Islam, bukan gambaran secara normatif. Realitas dan angka-angka statistik dibiarkan berbicara sendiri tentang dirinya. Sementara, pemikiran keagamaan selama ini hanya bertumpu pada model "pengalihan" yang hanya memindahkan bunyi teks kepada realitas, padahal metode teks seperti itu membutuhkan pembuktian. Sebab, ia hanya memperjuangkan orang-orang Islam sebagai suatu prinsip, tetapi tidak memperjuangkan muslim sebagai rakyat. Terakhir, walaupun mengarah pada realitas, metode teks secara maksimal hanya akan memberikan status tapi tidak menjelaskan perhitungan kuantitatif. Padahal, sesungguhnya umat Islam membutuhkan penjelasan terhadap realitas sampai kepada fakta "siapa

${ }^{26}$ Ibid., 9.

${ }^{27}$ Ibid., 9. Lihat juga Hanafi, Oksidentalisme..., 34.

${ }^{28}$ Ibid., 10. 
milik apa”. Metode Kiri Islam adalah metode kuantitatif dengan angka-angka dan statistik sehingga realitas dapat berbicara mengenai dirinya sendiri. ${ }^{29}$

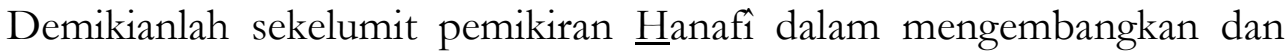
mengusung gagasan Kiri Islam sebagai bentuk pemikiran independen dalam tradisi pemikiran. Hal itu dilakukan tentunya dalam rangka membangun umat Islam pada kondisi dunia yang lebih meyakinkan, sehingga dapat mengejar ketertinggalannya dari dunia lainnya (terutama Barat).

\section{Catatan Akhir}

Lewat karyanya, al-Yasâr al-Islâmî, ㅂassan Hanafî nampaknya banyak menggunakan ungkapan tajam daripada ungkapan arif nan "menyenangkan". Dengan kata lain, ia lebih mendahulukan istilah "nahi mungkar" daripada "amar ma'ruf". Hal itu dimaksudkan untuk lebih menarik perhatian orang tentang suatu problema kekinian yang dialami dunia Islam. Kendati gagasan Kiri Islam muncul dalam waktu relatif singkat, tapi ide-ide revolusioner yang ia tuangkan di dalamnya menjadikan Hanafî terkenal dalam percaturan intelektual muslim dunia.

Gagasan Kiri Islam yang dikembangkan $\underline{H} a s a n$ Hanafî dapat dianggap sebagai sebentuk revolusi berpikir. Walau demikian, ide yang dinilai revolusioner tersebut, tidak lepas dari kritikan juga. Tunjuk misal kritik ajuan Issa J. Boullata yang menganggap ide Hanafí terlalu teoretis untuk dipraktikkan. Rekonstruksi yang diikhtiari Hanafí dianggapnya masih beraroma romantisme, sehingga belum begitu membumi. Selain itu, ia terlalu optimis bahwa seluruh karyanya akan dapat mengubah kondisi umat Islam secara revolusioner. Walaupun demikian, kritik dan pemikiran $\underline{\text { Hanafî dalam }}$ gagasan Kiri Islam sesungguhnya dapat menyumbangkan sesuatu yang sangat berharga (terutama dalam jagat diskursus islamic studies) bagi kepentingan Islam dan kaum muslimin.

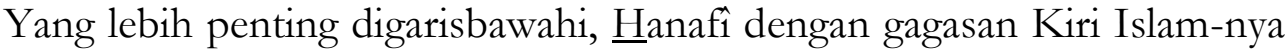
tampak berupaya melakukan desentralisasi dominasi Barat melalui oksidentalisme yang ia perhadapkan dengan orientalisme. Hal ini merupakan sebentuk kegelisahan dan "ratapan" intelektualnya atas menglobalnya kebudayaan Barat dan telah menjadi standar kebenaran universal dalam setiap dimensi kehidupan. Bagi Hanafî, kenyataan ini perlu didobrak dan dibongkar (dalam makna "desentralisasi”) hingga ke taraf pembebasan.

\footnotetext{
29Ibid., 12.
} 
Dalam kerangka itu, oksidentalisme diamanahkan mengekspresikan kemampuan "ego" sebagai emosi yang netral dalam memandang "the other" (baca: Barat), mengkajinya, dan mengubahnya menjadi objek, setelah sekian lama "the other" (Barat) menjadi subjek (melalui kajian orientalisme), yang menjadikan pihak lain (baca: Timur-Islam) sebagai objek. Sekali lagi, oksidentalisme dibangun di atas "ego" yang netral dan tidak berambisi merampas kekuasaan dan dominasi Barat, kecuali hanya menghendaki pembebasan (liberation) dari ketertindasan timur (umat Islam), tentunya, dari Barat (baca: Eropa dan Amerika). Di situlah makna klausa "perlunya menentang peradaban Barat". 